\title{
Physicochemical characteristics of black garlic from 'Hongsan' variety
}

\author{
Min Jung Kang, Jae Ran Kang, Jung Hye Shin* \\ Namhae Garlic Research Institute, Namhae 52430, Korea \\ 홍산 품종으로 제조한 흑마늘의 이화학적 특성 \\ 강민정 - 강재란 · 신정혜* \\ (재)남해마늘연구소
}

\begin{abstract}
The present study aimed to confirm the quality characteristics of black garlic aged from 'Hongsan' variety developed by the National Institute of Horticultural and Herbal Science and the 'Namdo' variety cultivated mainly in Namhae-gun. The total phenolic compounds of aged Hongsan and Namdo garlic increased 1.3- and 1.7-fold, respectively, and total flavonoid contents increased 8.6- and 11.2-flod, respectively. The content of pyruvate and thiosulfinate decreased with aging in both garlic varieties. The S-allyl cysteine (SAC) contents of Hongsan and Namdo garlic were maximal on day 6 and 2 of aging, respectively, before decreasing. The abundance of $\gamma$-glutamyl S-allyl cysteine $(\gamma$-GSAC) was -2.2-fold higher in fresh Hongsan, than fresh Namdo garlic, and increased to -6-fold after aging. The moisture, pH, acidity, reducing sugar, total sugar, pyruvate, and thiosulfinate contents of aged black garlic did not significantly differ between the two garlic varieties, but the total phenolic compounds and total flavonoids were higher in aged Namdo garlic, whereas hardness, SAC, and $\gamma$-GSAC contents were higher in aged Hongsan garlic. The contents of fresh garlic are assumed to be responsible for these difference between the two varieties of aged black garlic.
\end{abstract}

Key words : black garlic, hongsan, namdo garlic, S-allyl cysteine, $\gamma$-glutamyl S-allyl cysteine

\section{서 론}

대표적인 마늘 가공품인 흑마늘은 첨가물 없이 생마늘을 $60-80^{\circ} \mathrm{C}$ 에서 습도를 조절하면서 10 일-3개월 정도 숙성시켜 서 얻어지는데, 이러한 열처리 숙성 조건 동안에 Maillard 반 응과 효소적 반응이 일어나 마늘의 색이 검어지고 향이나 맛, 화학적 조성이 변화된다(Kim 등, 2012). 흑마늘은 외관이나 관능적 특성뿐만 아니라, 이화학적으로도 생마늘과 차별화되 는 특성을 가지는데, 열처리 숙성 과정에서 생산되는 Maillard 반응 물질 이외에 페놀화합물, 플라보노이드 등과 같은 항산 화성 물질과 더불어 $S$-allyl cysteine(SAC)과 같은 기능성 성 분을 지니게 된다(Kimura 등, 2017). 흑마늘의 대표적인 생
리활성 물질로 알려져 있는 SAC는 allyl chloride, allyl bromide, sodium allyl sulfide와 allyl nitrite를 포함하는 allyl halide나 ester가 glutamate 또는 glutathione과 결합하여 얻어 진 대사산물로 알려져 있는데, S-allyl glutathione의 glutamate 와 glycine 잔기는 $\gamma$-glutamyl transpeptidase $(\gamma$-GTP)와 dipeptidase에 의해 분해되어 생성된다(Krause 등, 2002). 한편 으로 SAC는 $\gamma$-GTP가 불활성화되는 열처리 조건에서는 alliin으로부터 직접 생성되기도 한다(Chen 등, 2017). 효소와 비효소적 반응에 의해서 생성된 SAC는 산화 스트레스를 개 선하고, 항산화 방어 시스템을 강화하며(Ashafaq 등, 2012), 신경보호(Garcia 등, 2014)와 망막보호(Chao 등, 2014) 효과 및 항염증과 세포자사의 방지 효과(Colin-Gonzalez 등, 2015)

*Corresponding author. E-mail : whanbee@daum.net, Phone : +82-55-860-8947, Fax : +82-55-860-8960

Received 07 July 2020; Revised 29 July 2020; Accepted 30 July 2020.

Copyright (c) The Korean Society of Food Preservation.

This is an Open Access article distributed under the terms of the Creative Commons Attribution Non-Commercial License (http://creativecommons.org/licenses/by-nc/4.0) which permits unrestricted non-commercial use, distribution, and reproduction in any medium, provided the original work is properly cited. 
등과 같은 생리기능을 가지는 것으로 알려져 있다.

국내에서 흑마늘과 관련한 연구는 2006년부터 시작되어 흑마늘을 숙성시키는 장치와 숙성 조건 확립, 흑마늘을 이용 한 가공식품의 개발, 흑마늘의 다양한 생리활성 규명에 대한 연구 등 다양한 측면에서 연구가 진행되고 있다. 최근 5년간 흑마늘과 관련한 연구로는 방사선 조사시 흑마늘 추출물의 혈구 및 장점막에 대한 보호 효과(Jung 등, 2016) 및 흑마늘 을 첨가한 김치소(Lee와 Yoon, 2017), 와인(Ha 등, 2016), 간 장(Sim 등, 2016), 식초(Seo 등, 2016)의 제조와 관련한 연구 들이 진행되어 있다. 하지만 마늘과 같이 토양에 재배하는 대 부분의 작물 등은 기본적으로 토양의 화학성분 조성에 따라 생육 및 성분의 차이를 보이는데, 재배식물의 수량 증가와 관 련하여서는 작물의 종류나 재배 지역에 따라 차이는 있지만 품종은 약 $50 \%$, 그 외에는 재배기술이나 기상요인 등이 영향 을 미치게 된다(Kim과 Ra, 2019b). 따라서 흑마늘의 품질이 나 이화학적 특성은 원료 마늘의 특성과 더불어 숙성 온도, 시간 등 가공 조건이 영향을 미치지만, 아직까지 이와 관련하 여서는 코끼리 흑마늘과 일반 흑마늘의 항산화활성 비교 (Kim 등, 2019)와 동결처리를 통해 흑마늘 숙성 공정을 개선 하고자 한 연구(Choi 등, 2017)가 있을 뿐이다.

신품종 마늘인 ‘홍산’은 국제 신품종보호연맹 협약으로 인 해 품종보호 작목으로 지정된 마늘의 육종을 위하여 개발된 것으로 2003년 임성자원 ' 8902 '와 '9209'간의 교배조합으로 얻은 진성 종자 중에서, 최종 선발된 12 번째 종자로부터 유래 한 마늘구의 영양번식을 통하여 생산력검정시험과 3년간의 지역적응시험을 거쳐 2014년도에 육성되어 품종보호권(제 6320호, 2016년)이 등록되었다(Kim과 Ra, 2019a; RDA, 2018). 홍산은 1976년 홍콩에서 중국 가정 지방의 가정백마 늘을 도입육종을 위해 들여와 남해, 해남, 제주에서 생산력 검정을 거쳐 우량종을 선발하여 1983년 품종화하면서 명명 된 남도마늘(RDA, 2017) 이상으로 월등히 수량이 높고 한지 와 난지 모두 재배가 가능하며, 기능성 성분이 높고, 천근성으 로 뿌리가 현저하게 적어 수확이 쉬워 생력재배에 알맞다고 알려져 있다(RDA, 2018; RDA, 2019). 홍산 품종의 단점으 로는 구의 선단부위에 클로로필로 인해 연한 녹색을 띄는 특 징이 있어(NIHHS, 2015) 소비자가 녹변 발생으로 오인 가능 성이 높아 개선이 요구되지만 마늘의 외형이 우수하여 흑마 늘 제조시 통벌어짐 현상으로 인해 상품성이 떨어지는 난지 형 마늘의 단점을 보완할 수 있다.

홍산은 최근에 선발된 품종이라는 특성으로 인하여 재배 외에 식품학적 관점에서 접근한 연구는 식물화학적 구성 및 생리활성(Kim과 Ra, 2019a)에 대한 보고와 남해와 제주, 전 주에서 각각 재배한 홍산 마늘의 alliin 함량을 비교한 결과 재배 지역에 따른 통계적인 유의차가 없었으며, 토양의 질소
비율이나 토양 조성 등과 같은 재배환경이 중요한 영향인자 라는 보고(Han, 2019)만이 진행되어 있어 관련한 다양한 연 구들이 진행될 필요성이 있다.

본 연구에서는 남해군에서 재배한 홍산과 대표적인 재배 품종인 남도마늘로 흑마늘을 각각 제조하여 이들의 이화학적 특성과 더불어 흑마늘로 숙성된 후 이들 성분의 변화를 비교 분석함으로써 가공특성 확인을 위한 기초자료를 확보하고자 하였다.

\section{재료 및 방법}

\section{시료 제조}

홍산은 농촌진흥청으로부터 분양 받은 것을 남해군에서 재배 - 수확하여 농가에서 2주 정도 건조한 상태로 출하한 것 을 사용하였으며, 남도마늘도 남해군 관내에서 재배되어 홍 산과 동일한 과정을 거쳐 건조, 출하된 것을 사용하였다. 흑 마늘 제조는 (재)남해마늘연구소 특허(2019)에 따라 $45^{\circ} \mathrm{C}$ 에 서 시작하여 $85^{\circ} \mathrm{C}$ 까지 상승시켰다가 다시 온도를 $60^{\circ} \mathrm{C}$ 까지 서서히 내리는 조건에서 항온항습기를 이용하여 12 일 동안 숙성하였다. 통마늘 상태의 생마늘을 0 일 차 시료로 하고, 2 일 간격으로 시료를 채취하여 분석용 시료로 사용하였다.

\section{색도 측정}

마늘 시료는 껍질을 제거한 다음 색차계(Ultra scan VIS, Hunter Associates Lab. Inc., Reston, VA, USA)를 이용해 시 료의 표면색을 측정하였다. 이 때 표준색판의 $\mathrm{L}, \mathrm{a}, \mathrm{b}$ 값은 각각 99.4, -0.12 및 0.04였으며, 각 숙성 일차별로 10 개씩의 시료를 취하여 색도를 측정하였다.

\section{경도 측정}

껍질을 제거한 마늘을 $7 \mathrm{~mm}$ 두께로 슬라이스한 다음 물 성측정기(TAXT express, Stable Micro Systems, Godalming, Surrey, UK)를 이용하여 각 시료군당 10 개 이상의 시료를 취 하여 전단가를 측정하였다. 이 때 분석 조건으로는 $\Phi 4 \mathrm{~mm}$ core를 사용하였고, pre-test speed는 $1.0 \mathrm{~mm} / \mathrm{s}$, tigger force $50.0 \mathrm{~g}$, test speed $5.0 \mathrm{~mm} / \mathrm{s}$, test distance $5.0 \mathrm{~mm}$, test cycle 은 1.0 이었다.

\section{수분, $\mathrm{pH}$, 산도, 총당 및 환원당 측정}

수분은 껍질을 제거한 마늘을 분쇄기로 분쇄한 후 $1 \mathrm{~g}$ 을 취하여 자동수분측정기(MB45, Ohaus, Zürich, Switzerland) 로 측정하였다.

숙성 일차별 마늘을 분쇄한 시료 $10 \mathrm{~g}$ 에 정제수를 가하여 혼합 분쇄한 후 $100 \mathrm{~mL}$ 가 되도록 정용하였다. 이를 충분히 
혼합 교반하여 추출한 다음 여과한 시료액을 분석용 시료로 사용하였다. $\mathrm{pH}$ 와 산도는 여과한 여액 $50 \mathrm{~mL}$ 를 취하여 자동 적정기(G20 compact titrator, Mettler toledo, Columbus, $\mathrm{OH}$, USA)를 이용해 동시에 분석하였다. 총당의 함량은 황산페놀 법을 이용하여 여과한 마늘 시료액 $1 \mathrm{~mL}$ 에 $5 \%$ 페놀 용액 $1 \mathrm{~mL}$ 및 진한 황산 $5 \mathrm{~mL}$ 를 차례로 가하여 30 분간 실온에서 정치시킨 후 분광광도계(Libra S 35, Biochrom, Cambridge, England)로 $470 \mathrm{~nm}$ 에서 비색 정량하였다. 표준당으로 맥아 당(Sigma-Aldrich Co., St, Louis, MO, USA)을 사용하여 표 준검량곡선을 작성하고, 이에 따라 총당의 함량을 산출하였 다. 환원당의 함량은 $\mathrm{DNS}$ 법에 따라 추출 여과한 다음 정제 수로 10 배 희석한 시료액 $1 \mathrm{~mL}$ 에 DNS시약 $3 \mathrm{~mL}$ 을 가한 후, 끓는 물에서 15 분간 중탕 가열한 다음 찬물에서 냉각하여 $570 \mathrm{~nm}$ 에서 흡광도를 측정하고, 포도당(Sigma-Aldrich Co.) 을 표준물질로하여 작성한 검량곡선에 따라 정량하였다.

\section{총폴리페놀 및 총플라보노이드 정량}

총페놀화합물은 Foiln-Denis 방법(1915)에 따라 시료 무게 대비 10 배의 정제수를 가하여 진탕 혼합한 다음 여과한 여액 $1 \mathrm{~mL}$ 에 Foline-Ciocalteau 시약 $0.5 \mathrm{~mL}$ 를 넣고 3 분 후 $10 \%$ $\mathrm{Na}_{2} \mathrm{CO}_{3}$ 용액 $0.5 \mathrm{~mL}$ 씩을 혼합하여 실온의 암실에서 1 시간 정 치한 다음 분광광도계(Libra S 35, Biochrom)로 $760 \mathrm{~nm}$ 에서 흡광도를 측정하여 정량하였다. 표준물질로 gallic acid(SigmaAldrich Co.)를 사용하여 시료와 동일한 방법으로 분석하여 얻은 검량선으로부터 총페놀화합물의 함량 $(\mathrm{GAE} \mathrm{mg} / \mathrm{g})$ 을 산 출하였다.

총플라보노이드 함량은 Moreno 등(2000)의 방법에 따라 시료액 $1 \mathrm{~mL}$ 에 $10 \%$ aluminum nitrate $0.2 \mathrm{~mL}, 1 \mathrm{M}$ potassium acetate $0.2 \mathrm{~mL}$ 및 $80 \%$ ethanol $4.1 \mathrm{~mL}$ 를 차례로 가한 후 혼합하여 실온의 암실에서 40 분간 정치한 다음 분광광도 계(Libra S 35, Biochrom)로 $415 \mathrm{~nm}$ 에서 흡광도를 측정하여 정량하였다. Quercetin(Sigma-Aldrich Co.)을 표준물질로 하 여 얻은 검량선으로부터 총플라보노이드 함량 $(\mathrm{QE} \mathrm{mg} / 100 \mathrm{~g})$ 을 계산하였다.

\section{Total pyruvate 및 total thiosulfinate 정량}

Schwimmer와 Weston(1961)의 방법에 따라 분쇄한 마늘 $1 \mathrm{~g}$ 에 $10 \%$ trichloroacetic acid $5 \mathrm{~mL}$ 를 첨가한 다음 균질화 하여 1 시간 방치한 후 여과지로 여과하였다. 이 여액 $1 \mathrm{~mL}$ 에 $0.0125 \%$ dinitriphenylhydrazine $1 \mathrm{~mL}$ 를 가하여 잘 혼합한 다음 $37^{\circ} \mathrm{C}$ 에서 10 분간 반응시키고, $0.6 \mathrm{~N} \mathrm{NaOH}$ 용액 $5 \mathrm{~mL}$ 를 가하여 $420 \mathrm{~nm}$ 에서 흡광도를 측정하였다. 표준용액으로 sodium pyruvate를 $0.2 \mu \mathrm{M}$ 의 간격으로 농도 조정해 동일한 방법으로 실험하여 얻은 표준검량곡선으로부터 total pyruvate 의 함량을 산출하였다.
Thiosulfinate는 Freeman과 Mcbreen(1973)의 방법에 따라 2 $\mathrm{mM}$ cysteine이 함유된 $\mathrm{pH} 7.5$ 의 $50 \mathrm{mM} \mathrm{N}$-[2-Hydroxyethyl] piperazine- $N$-2-ethane sulfonic acid(HEPES) 용액 $0.5 \mathrm{~mL}$ 와 시료에 일정량의 정제수를 가하여 추출 여과한 여액 $0.1 \mathrm{~mL}$ 를 혼합한 후 $50 \mathrm{mM} \mathrm{HEPES}$ 를 가하여 총 반응용액의 부피 를 $5 \mathrm{~mL}$ 로 만든 다음 $27^{\circ} \mathrm{C}$ 에서 10 분간 반응시켰다. 이 반응 액 $1 \mathrm{~mL}$ 를 취하여 $50 \mathrm{mM}$ HEPES로 제조한 $0.4 \mathrm{mM}$ 5,5'-dithio-bis 2-nitrobenzoic acid(DTNB) $1 \mathrm{~mL}$ 를 가하여 잘 혼합한 후 다시 $27^{\circ} \mathrm{C}$ 에서 10 분간 반응시킨 다음 $412 \mathrm{~nm}$ 에서 흡광도를 측정하였다. $50 \mathrm{mM}$ HEPES로 제조한 0.05-0.3 $\mathrm{mM}$ 의 cysteine 용액을 표준물질로 하여 시료와 동일한 방법 에 따라 흡광도를 측정한 결과를 이용해 표준검량곡선을 작 성하여 마늘 중의 total thiosulfinate 함량을 산출하였다.

\section{S-Allyl-cysteine(SAC) 및 $r$-glutamyl-S-allyl-cysteine $(r-\mathrm{GSAC})$ 정량}

$\mathrm{SAC}$ 와 $\gamma$-GSAC는 동일한 방법으로 전처리한 후 동일한 조건에서 분석하였다. 즉, 시료 $5 \mathrm{~g}$ 에 3차 정제수 $45 \mathrm{~mL}$ 를 가하여 균질화한 후 30 분간 sonication하여 추출한 다음 여과 지로 여과한 여액을 $0.22 \mu \mathrm{m}$ membrane filter로 재여과하여 HPLC-PDA-MS/MS(TSQ Quantum LC-MS/MS, Thermo scientific, Waltham, MA, USA)로 분석하였다. 분석용 컬럼 은 Agilent Zorbax SB-C $\mathrm{C}_{18}(4.6 \times 250 \mathrm{~mm}, 5 \mu \mathrm{m}$, Agilent Technologies, Santa clara, CA, USA)을 사용하였고, 양이온 모드에서 이동상 용매는 $0.1 \%$ formic acid 수용액과 acetonitrile에 용해한 $0.1 \%$ formic acid를 시간에 따라 혼합 비율을 조절하였다. SAC(Sigma-Aldrich Co.)와 $\gamma$-GSAC (US Pharmacopeia, MD, USA) 표준물질을 시료와 동일한 조건에서 분석하여 머무름 시간을 비교해 확인하였으며, 각 각의 표준 검량곡선으로부터 함량을 산출하였다.

\section{통계처리}

모든 실험은 3회 이상 반복하여 실시하였으며, 실험으로부 터 얻은 결과는 SPSS statistics 18(IBM, Armonk, NY, USA) 통계 package를 이용하여 분석하였다. 결과는 평균 \pm 표준편 차로 표시하였고, 실험군에 따른 데이터간의 통계적 유의성 검정을 위해 Duncan's multiple range test, ANOVA 및 t-test 를 수행하였다 $(\mathrm{p}<0.05)$.

\section{결과 및 고찰}

\section{흑마늘 숙성에 따른 색 변화}

홍산과 남도마늘로 흑마늘을 숙성하면서 색의 변화를 분 석한 결과는 Fig. 1 과 같다. 생마늘에서 홍산과 남도마늘 각 
각의 명도는 82.0과 83.7로 서로간에 유의적인 차이가 없었 으며, 숙성이 시작되면서 급격하게 감소하여 숙성 2 일 차에 홍산은 46.0 으로 생마늘에 비해 약 $44 \%$, 남도마늘은 40.9 로 약 $51 \%$ 가 감소하였다. 이후부터는 감소폭이 줄어 완만히 감 소하였고, 숙성 2 일에서 8 일까지는 홍산에서 유의적으로 더 높은 값을 유지하였으나, 숙성 10 일 이후부터는 품종에 따른 차이가 없었고, 숙성 12 일에 홍산과 남도마늘의 명도는 각각 29.2와 29.9로 낮아졌다.

적색도는 생마늘에서는 마늘 품종에 관계없이 동일하게 -1.9 였으나, 숙성 2 일에 급격히 증가하여 홍산은 6.0 , 남도마 늘은 7.0 으로 최고치를 보였다. 이후 숙성기간의 경과와 더불 어 감소하는 경향을 보였는데, 홍산은 숙성 8 일에, 남도마늘 은 숙성 10 일에 각각 한 차례씩 적색도가 증가한 후 다시 감 소하였다.

생마늘의 황색도는 홍산에서 20.1, 남도마늘은 18.6 이었으 며, 서로간에 통계적인 유의차는 없었다. 황색도는 숙성 초기 에 급격히 감소하였는데, 숙성 4 일에는 숙성 2 일에 비해 홍산 은 $62.7 \%$, 남도마늘은 $74.4 \%$ 낮아졌다. 이후 홍산은 숙성

(A)

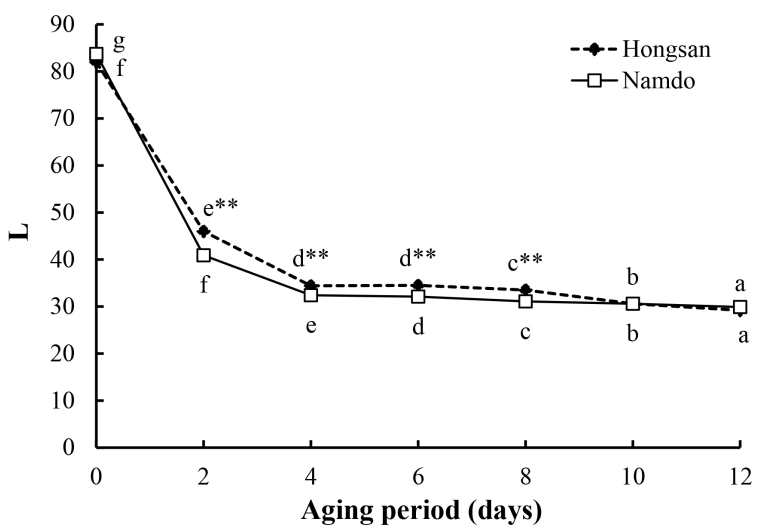

(C)

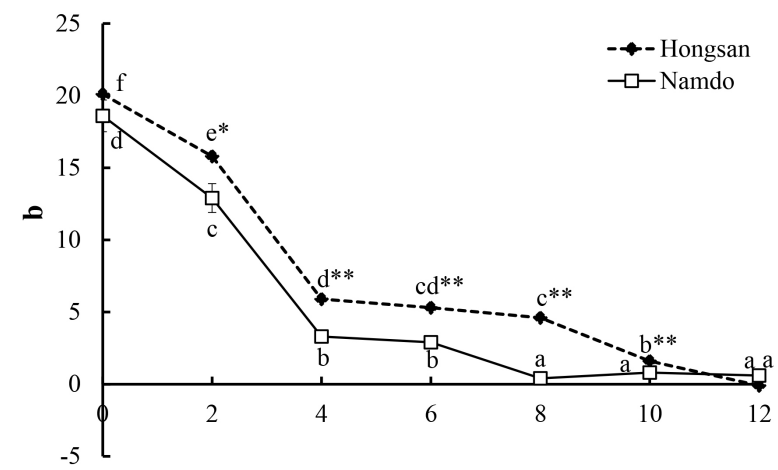

4-8일까지는 감소폭이 완만하였다가 다시 유의적으로 감소 하였고, 남도마늘은 숙성 8 일에 유의적인 감소를 보인 후 숙 성 완료시까지 유의적인 차이가 없었다. 숙성 기간 동안 황색 도는 홍산이 남도마늘보다 유의적으로 더 높았으나, 숙성이 완료된 숙성 12 일에는 서로간에 유의차가 없었다.

흑마늘을 제조하는 과정 중의 색의 변화를 육안으로 관찰 하면 대부분의 마늘이 숙성 초기에 급격히 갈변이 일어나고, 숙성 3-4일 정도에 내부까지 진한 갈색으로 변한 다음 숙성 이 계속되면서 전체적으로 검은색이 더 진해진다. 색의 분석 결과, 명도, 적색도 및 황색도 모두 숙성 초기에 급격히 감소 하고, 이후부터는 서서히 변화를 보이는 것은 이러한 육안 관 찰의 결과와 일치하였다.

이상의 색 분석 결과로부터 흑마늘의 숙성 과정에서는 명 도보다 적색도나 황색도가 더 큰 영향을 받지만, 숙성이 완료 된 이후에는 유의적인 차이가 없어 마늘의 품종은 흑마늘의 색과 관련한 품질에는 영향을 미치지 않음을 알 수 있었다. 흑마늘 숙성 중 껍질의 유무와 숙성 온도를 달리하였을 때 숙성 초기의 명도 값은 서로 상이하지만, 숙성이 완료된 후에
(B)

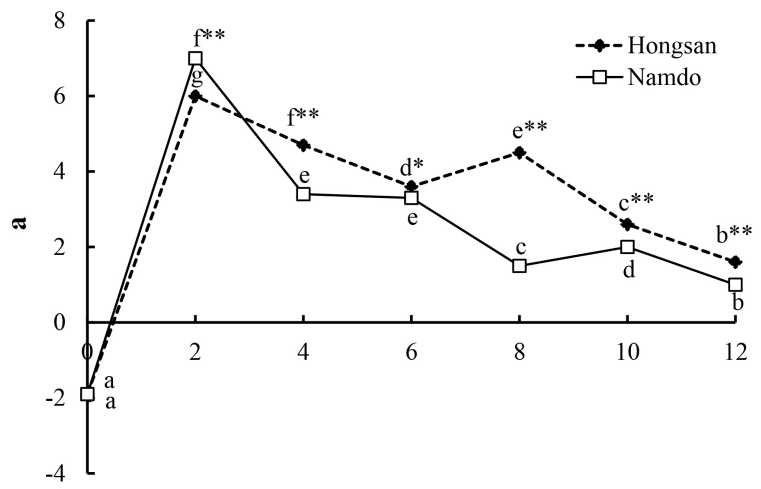

Aging period (days)

Aging period (days)

Fig. 1. Changes in L (A), a (B) and b (C) color values according to the aging period of black garlic from 'Hongsan' and 'Namdo' varieties. All data are showed as mean \pm SD $(n=10)$. Different lower case letters indicate the significant differences between aging dates by Duncan's multiple range test $\mathrm{p}<0.05$. "Marks indicate the significant differences between the same aging days by Student's t-test ${ }^{*}<0.05$ and ${ }^{* * *} \mathrm{p}<0.01$. 
는 모두 유사한 범위였다는 보고(Angeles 등, 2016)는 본 연 구의 결과와도 일치하였다.

\section{흑마늘 숙성에 따른 경도 변화}

흑마늘 숙성에 따른 경도의 변화는 Fig. 2 와 같다. 생마늘 의 경도는 홍산에서 $1,626.8 \mathrm{~g}$ 으로 남도마늘 $(1,068.7 \mathrm{~g})$ 에 비 해 유의적으로 높았는데, 숙성이 시작되면서 급격히 감소하 여 숙성 2일에 홍산은 $175.3 \mathrm{~g}$, 남도마늘은 $278.4 \mathrm{~g}$ 으로, 남 도마늘에서 유의적으로 더 높았다. 숙성 2 일부터 숙성이 완 료되는 12 일까지 홍산의 경도는 경미한 변화가 있었으나 통 계적인 유의차는 없었다. 남도마늘은 숙성 6 일에 유의적인 증가 후에 다시 감소하였다가 숙성 10 일 이후에는 유의적인 변화가 없었다. 숙성 10 일 이후부터는 홍산의 경도가 남도마 늘에 비해 유의적으로 더 높았는데, 숙성 12 일에 홍산은 $143.6 \mathrm{~g}$, 남도마늘의 경도는 $70.5 \mathrm{~g}$ 였다. 이러한 경도의 변화 는 흑마늘의 숙성 초기에는 가공 과정에서의 열처리로 인하 여 마늘 조직이 물러지지만, 숙성 기간이 경과함에 따라 점차 수분이 감소됨으로써 육질이 단단해지기 때문으로 추정한 보 고(Shin 등, 2008)로 미루어 볼 때 숙성 기간 동안 경도의 증 감은 수분의 함량 변화와 관련이 있을 것으로 추정된다.

$\mathrm{Cha}(2012)$ 는 흑마늘의 숙성 초기 경도는 생마늘에 비해 약 $85 \%$ 낮아지고, 이후 숙성기간이 경과함에 따라 유의적으 로 증가하였다고 보고한 바 있으며, Kang 등(2011)은 홍마늘 을 숙성시키는 동안 경도는 숙성 초기에 생마늘에 비해 유의 적으로 감소한 후 숙성 중기까지는 유의적인 변화가 없다가 숙성 말기에 증가하였다고 보고한 바 있다. 이들 결과는 생마

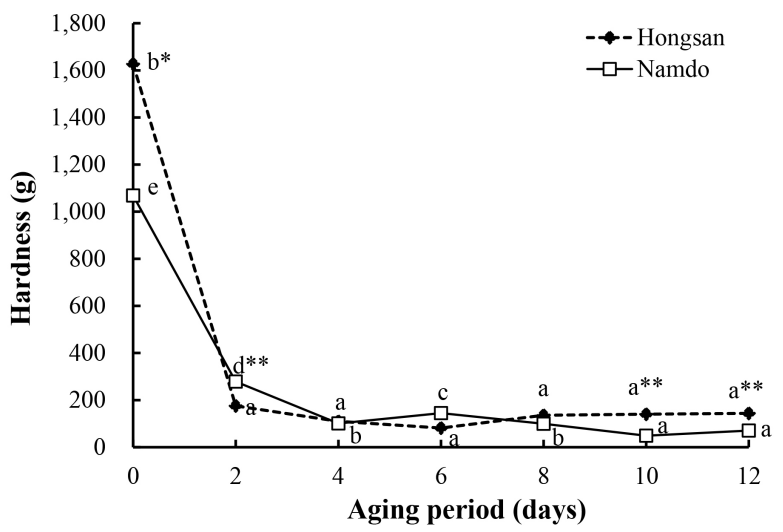

Fig. 2. Changes in hardness according to the aging period of black garlic from 'Hongsan' and 'Namdo' varieties.

All data are showed as mean \pm SD $(n=10)$. Different lower case letters indicate the significant differences between aging dates by Duncan's multiple range test $p<0.05$. *Marks indicate the significant differences between same aging days by Student's t-test ${ }^{*} \mathrm{p}<0.05$ and ${ }^{* *} \mathrm{p}<0.01$.
늘에 비해 숙성 초기의 마늘 경도가 급격히 낮아진다는 점에 서는 일치하였으나, 숙성 기간에 따른 경도 변화에서는 다소 차이가 있었다. 이와 관련하여 마늘의 숙성 온도가 $90^{\circ} \mathrm{C}$ 로 높 을 경우 경도는 숙성기간의 경과와 더불어 증가하지만 숙성 온도가 $60^{\circ} \mathrm{C}$ 정도로 낮을 때는 상반된 경향을 보이며, $70^{\circ} \mathrm{C}$ 정도에서는 숙성 초기에 비해 낮아진 후 변화의 폭이 적다는 Shin 등(2008)의 보고로 미루어 볼 때 기존 연구의 결과들과 본 연구의 결과간의 차이는 마늘의 숙성 온도가 서로 간에 상이하였기 때문으로 생각된다.

\section{흑마늘 숙성에 따른 수분, $\mathrm{pH}$ 및 산도 변화}

홍산과 남도마늘로 각각 흑마늘을 제조하면서 수분, $\mathrm{pH}$ 및 산도의 변화를 분석한 결과는 Table 1 과 같다. 흑마늘 숙 성과정 중 홍산과 남도마늘 모두 수분과 $\mathrm{pH}$ 는 지속적으로 감 소하고, 산도는 증가하는 경향이었다.

수분은 생마늘에서 홍산은 $58.14 \mathrm{~g} / 100 \mathrm{~g}$, 남도마늘은 59.68 $\mathrm{g} / 100 \mathrm{~g}$ 이었는데, 홍산은 숙성 2일 이후에 수분 함량은 50 $\mathrm{g} / 100 \mathrm{~g}$ 이하로 낮아진 것에 반해 남도마늘은 숙성 6일까지 $50 \mathrm{~g} / 100 \mathrm{~g}$ 이상을 유지하였다. 홍산의 수분은 숙성 10 일에 $37.08 \mathrm{~g} / 100 \mathrm{~g}$ 으로 낮아졌으나, 남도마늘의 수분은 숙성 12 일에 $39.84 \mathrm{~g} / 100 \mathrm{~g}$ 으로 홍산에 비해 유의적으로 더 높았다.

생마늘의 $\mathrm{pH}$ 는 홍산에서 6.74로 남도마늘(6.26)보다 유의 적으로 더 높았으며, 숙성기간 동안에도 남도마늘에 비해 홍 산의 $\mathrm{pH}$ 가 유의적으로 더 높았다. 홍산의 경우 숙성 10 일까 지도 $\mathrm{pH}$ 는 5.0 이상이었으며, 숙성 12 일에 4.65로 낮아졌으 나 남도마늘의 경우 숙성 8 일에 $\mathrm{pH}$ 는 4.75 로 낮아진 이후에 도 지속적으로 낮아져 숙성 12 일에는 4.22 였다.

흑마늘 숙성 과정 중 $\mathrm{pH}$ 의 저하는 열처리 공정 동안 마늘 의 세포 파괴로 인한 조직 내부 유기산들의 유리(Yuan 등, 2018), 열처리에 의한 갈변물질의 다량 생산 반응에서 환원 당인 aldohexose의 aldehyde기의 산화에 따른 carboxyl기 생 성, 당과 염기성 아미노산의 결합에 의한 가용성 염기성 아미 노산의 감소 및 산성물질의 생성에 따른 것으로 $\mathrm{pH}$ 가 낮아지 면 갈변반응이 더 촉진된다고 알려져 있다(Choi 등, 1981; $\operatorname{Kim}$ 등, 1981).

산도는 숙성 4일까지는 품종에 따른 유의적인 차이가 없었 으나, 숙성 6 일부터는 남도마늘에서 유의적으로 더 높았다. 홍산의 경우 $\mathrm{pH}$ 의 변화와 상반되는 경향으로 숙성 2 일까지 는 유의적인 차이가 없었으며, 숙성 10 일에도 $0.15 \mathrm{~g} / 100 \mathrm{~g}$ 으 로 증가폭이 적었다가 숙성 12 일에 $0.24 \mathrm{~g} / 100 \mathrm{~g}$ 으로 증가하 였다. 남도마늘도 숙성 2일까지는 유의적인 변화가 없었으나, 숙성 8 일에 $0.25 \mathrm{~g} / 100 \mathrm{~g}$ 으로 증가한 후 숙성 12 일에는 0.34 $\mathrm{g} / 100 \mathrm{~g}$ 으로 홍산보다 약 1.4 배 더 높았다.

흑마늘 숙성 중에 일어나는 여러 성분들의 변화는 서로 연 
Table 1. Changes in moisture, $\mathrm{pH}$ and acidity according to the aging period of black garlic from 'Hongsan' and 'Namdo' varieties

\begin{tabular}{|c|c|c|c|c|}
\hline Species of garlic & $\begin{array}{c}\text { Aging period } \\
\text { (days) }\end{array}$ & $\begin{array}{l}\text { Moisture } \\
(\mathrm{g} / 100 \mathrm{~g})\end{array}$ & $\mathrm{pH}$ & $\begin{array}{l}\text { Acidity } \\
(\mathrm{g} / 100 \mathrm{~g})\end{array}$ \\
\hline \multirow{7}{*}{ 'Hongsan' } & 0 & $58.14 \pm 0.20^{1) f 2}$ & $6.74 \pm 0.03^{\left.\mathrm{g}^{* * 3}\right)}$ & $0.06 \pm 0.00^{\mathrm{a}}$ \\
\hline & 2 & $51.03 \pm 0.46^{\mathrm{e}}$ & $6.50 \pm 0.08^{*^{*}}$ & $0.07 \pm 0.00^{\mathrm{a}}$ \\
\hline & 4 & $43.40 \pm 0.55^{\mathrm{c}}$ & $5.82 \pm 0.04^{\mathrm{e}^{* *}}$ & $0.11 \pm 0.00^{\mathrm{b}}$ \\
\hline & 6 & $45.11 \pm 0.57^{\mathrm{d}}$ & $5.48 \pm 0.06^{\mathrm{d}^{*}}$ & $0.12 \pm 0.01^{\mathrm{bc}}$ \\
\hline & 8 & $44.86 \pm 0.36^{\mathrm{d}}$ & $5.39 \pm 0.02^{\mathrm{c}^{* *}}$ & $0.13 \pm 0.01^{\mathrm{c}}$ \\
\hline & 10 & $37.08 \pm 0.65^{\mathrm{b}}$ & $5.12 \pm 0.01^{\mathrm{b}^{* *}}$ & $0.15 \pm 0.01^{\mathrm{d}}$ \\
\hline & 12 & $34.35 \pm 0.25^{\mathrm{a}}$ & $4.65 \pm 0.02^{\mathrm{a}^{* *}}$ & $0.24 \pm 0.01^{\mathrm{e}}$ \\
\hline \multirow{7}{*}{ 'Namdo' } & 0 & $59.68 \pm 0.05^{\mathrm{g}^{* *}}$ & $6.26 \pm 0.02^{\mathrm{g}}$ & $0.10 \pm 0.00^{\mathrm{a}}$ \\
\hline & 2 & $53.27 \pm 0.05^{\mathrm{e}^{*}}$ & $6.22 \pm 0.00^{f}$ & $0.10 \pm 0.00^{\mathrm{a}}$ \\
\hline & 4 & $54.86 \pm 0.22^{\mathrm{f}^{* *}}$ & $5.46 \pm 0.02^{\mathrm{e}}$ & $0.15 \pm 0.00^{\mathrm{b}}$ \\
\hline & 6 & $50.47 \pm 0.35^{\mathrm{d}^{* *}}$ & $5.20 \pm 0.01^{\mathrm{d}}$ & $0.18 \pm 0.01^{\mathrm{c} * *}$ \\
\hline & 8 & $44.37 \pm 0.68^{\mathrm{c}}$ & $4.75 \pm 0.01^{\mathrm{c}}$ & $0.25 \pm 0.01^{\mathrm{d}^{* *}}$ \\
\hline & 10 & $43.39 \pm 0.20^{\mathrm{b}^{* *}}$ & $4.51 \pm 0.01^{\mathrm{b}}$ & $0.31 \pm 0.01^{\mathrm{e}^{* *}}$ \\
\hline & 12 & $39.84 \pm 0.68^{\mathrm{z}^{* *}}$ & $4.22 \pm 0.02^{\mathrm{a}}$ & $0.34 \pm 0.01^{\mathrm{f**}}$ \\
\hline
\end{tabular}

${ }^{1)}$ All data are showed as mean \pm SD $(n=3)$.

${ }^{2)}$ Different lower case letters indicate the significant differences between aging dates by Duncan's multiple range test $\mathrm{p}<0.05$.

${ }^{3)^{*}}$ Marks indicate the significant differences between same aging days by Student's t-test ${ }^{*} \mathrm{p}<0.05$ and ${ }^{* *} \mathrm{p}<0.01$.

계되어 있는데, 당이 분해되면서 acetic acid가 생성되고, hexose나 pentose의 $\alpha$-, $\beta$-dicarbonyl기가 절단되어 단쇄 carboxylic acid가 생성됨으로 인해 formic acid, succinic acid 및 3-hydroxypropionic acid 등이 생성되어 유기산의 함 량이 증가하여 산도 증가와 $\mathrm{pH}$ 저하가 일어나고, 단백질, 펩 타이드 및 다당류의 분해에 영향을 미치는 것으로 보고되어 있다(Liang 등, 2015).

\section{흑마늘 숙성에 따른 환원당 및 총당 변화}

홍산과 남도마늘의 숙성에 따른 환원당 및 총당의 변화를 분석한 결과는 Fig. 3 과 같다. 환원당의 함량은 숙성 2 일까지 는 증가폭이 미미하였으나, 숙성 4일 이후부터는 그 증가폭 이 더 커지면서 계속해서 증가하는 경향이었다. 숙성 전 홍산 과 남도마늘에서 환원당 함량은 각각 $3.34 \mathrm{~g} / 100 \mathrm{~g}$ 과 3.97 $\mathrm{g} / 100 \mathrm{~g}$ 으로 남도마늘에서 유의적으로 높았고, 숙성 10 일까 지는 동일한 경향이었다. 즉, 남도마늘의 경우 숙성 4 일에 환 원당 함량은 생마늘에 비해 약 3.6배 증가하여 $14.16 \mathrm{~g} / 100$ $\mathrm{g}$ 이었고, 숙성 8 일 이후부터는 $22.34 \mathrm{~g} / 100 \mathrm{~g}$ 이상이었으나, 홍산의 경우 숙성 10 일에서 $13.08 \mathrm{~g} / 100 \mathrm{~g}$ 이었고, 숙성이 완 료되는 숙성 12 일에야 $24.68 \mathrm{~g} / 100 \mathrm{~g}$ 으로 증가하여 남도마늘 과 유의적인 함량 차이가 없었다.

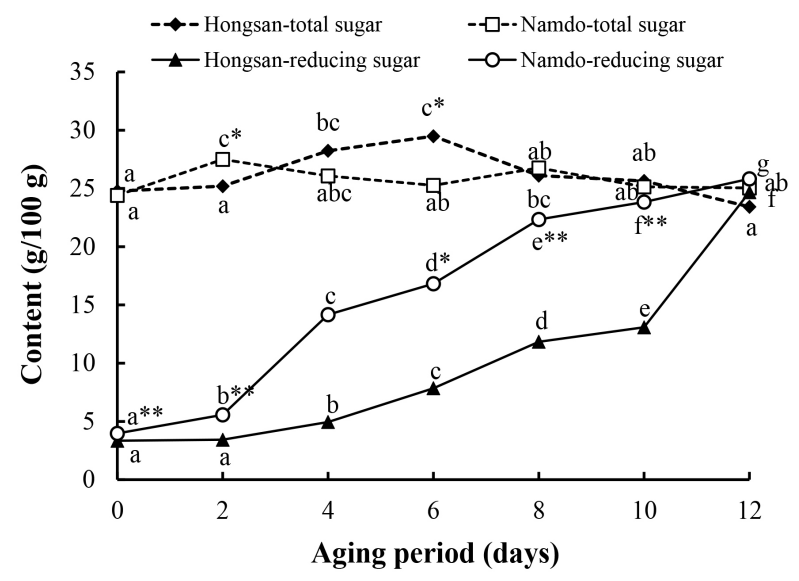

Fig. 3. Changes in reducing sugar and total sugar according to the aging period of black garlic from 'Hongsan' and 'Namdo' varieties.

All data are showed as mean \pm SD $(n=3)$. Different lower case letters indicate the significant differences between aging dates by Duncan's multiple range test $p<0.05$. * Marks indicate the significant differences between same aging days by Student's t-test ${ }^{*} \mathrm{p}<0.05$ and ${ }^{* *} \mathrm{p}<0.01$.

총당의 함량은 홍산에서 $23.42-28.23 \mathrm{~g} / 100 \mathrm{~g}$, 남도마늘에 서는 24.40-27.49 g/100 g의 범위에서 숙성기간의 경과와 더 불어 불규칙한 증감을 보였는데, 생마늘과 숙성 완료된 흑마 
늘에서 함량은 유의적인 차이가 없었다.

흑마늘 숙성 중 당류의 함량 변화와 관련하여 다당류의 분 해는 산성과 고온 조건하에서 일어나는데, 세포벽의 다당체 가 분해되면서 조직이 부드러워지고, 흑마늘의 질감이 검과 같이 변화하게 되며, 열처리 동안 $\mathrm{pH}$ 의 저하는 sucrose가 glucose나 fructose로 분해되는 것을 촉진함으로써 흑마늘 숙 성 동안 이들 당류의 함량이 증가한다고 보고되어 있다 (Liang 등, 2015).

한편, 환원당의 생성 속도와 관련하여 흑마늘 숙성 중 환 원당의 함량은 마늘 내 다당류가 분해되어 생성되는 양과 Maillard 반응 동안 소비되는 양에 의해 영향을 받는데, $70^{\circ} \mathrm{C}$ 이하의 온도에서는 환원당의 생성속도가 Maillard 반응 등에 소비되는 속도보다 빨라서 그 함량이 지속적으로 증가하지만 $80^{\circ} \mathrm{C}$ 이상에서는 숙성 초기는 환원당의 축적율이 소비량을 능가하여 그 함량이 증가하지만 고온으로 인해 Maillard 반 응 속도가 빨라짐에 따라 숙성 후기에는 그 함량이 오히려 감소한다고 보고되어 있다(Zhang 등, 2015).

마늘 중에는 건물량으로 약 $75 \%$ 의 다당류가 함유되어 있 으며, 이들의 주성분은 fructan으로(Baumgartner 등, 2000), fructose와 glucose가 14:1 정도의 비율로 혼합되어 있다 (Chen 등, 2013). Fructan은 흑마늘로 제조되는 열처리 공정 을 거친 후에 $84.79 \%$ 가 감소하며, 이와는 상반되게 fructose 함량은 $500 \%$ 이상 증가하며, glucose와 sucrose 함량에는 큰 차이가 없다는 보고가 있다(Yuan 등, 2018).

이상의 보고들과 비교하여 볼 때 본 연구의 결과에서는 상 대적으로 숙성 온도가 높은 초기에 환원당의 생성량이 증가 하였고, 이후 숙성 온도가 낮아지면서 갈변반응에 소비되는 환원당의 함량보다 다당류의 분해로 인해 생성되는 양이 더 많아져서 환원당의 함량은 증가하는 경향을 보인 것으로 생 각된다. 또한, 다당류의 분해가 유도되지만 상대적으로 유리 되는 가용성 당류의 함량 또한 증가함으로 인해 총당의 함량 변화에는 크게 영향을 미치지 않은 것으로 생각된다.

\section{흑마늘 숙성에 따른 총폴리페놀 및 총플라보노이드 변화}

흑마늘 숙성 과정 중 총페놀화합물 및 총플라보노이드는 숙성 기간의 경과와 더불어 점차 증가하는 경향이었다(Table 2). 총페놀화합물의 함량은 홍산과 남도마늘의 변화 경향이 서로 차이가 있었다. 즉, 홍산에서는 생마늘과 숙성 2일 차 마 늘간에 유의적인 함량 변화가 없었고, 숙성 10 일까지도 큰 함 량의 증가가 없어 생마늘에 비해 약 $9 \%$ 증가하였다가 숙성 12 일에 $4.87 \mathrm{GAE} \mathrm{mg} / \mathrm{g}$ 이었다. 남도마늘의 경우, 생마늘에 비 해 숙성 6 일에는 약 $16 \%$ 가 증가하여 $4.24 \mathrm{GAE} \mathrm{mg/g}$ 이었고, 숙성 12 일에는 약 1.8 배가 증가하여 $6.53 \mathrm{GAE} \mathrm{mg} / \mathrm{g}$ 이었다.

총플라보노이드 함량도 총페놀화합물과 유사한 경향으로
Table 2. Changes in total phenolics and flavonoid contents according to the aging period of black garlic from 'Hongsan' and 'Namdo' varieties

\begin{tabular}{|c|c|c|c|}
\hline $\begin{array}{l}\text { Species of } \\
\text { garlic }\end{array}$ & $\begin{array}{l}\text { Aging } \\
\text { days }\end{array}$ & $\begin{array}{l}\text { Total phenolic } \\
\text { compound } \\
\text { (GAE mg/g) }\end{array}$ & $\begin{array}{c}\text { Flavonoid } \\
(\mathrm{QE} \mathrm{mg} / 100 \mathrm{~g})\end{array}$ \\
\hline \multirow{7}{*}{ 'Hongsan' } & 0 & $3.66 \pm 0.01^{1 \mathrm{a} 2)}$ & $1.62 \pm 0.48^{\mathrm{a}}$ \\
\hline & 2 & $3.68 \pm 0.01^{\mathrm{a}}$ & $2.73 \pm 0.27^{\mathrm{a}}$ \\
\hline & 4 & $3.76 \pm 0.04^{\mathrm{b}}$ & $7.17 \pm 0.25^{\mathrm{b}}$ \\
\hline & 6 & $3.85 \pm 0.02^{\mathrm{c}}$ & $8.29 \pm 1.72^{b}$ \\
\hline & 8 & $3.92 \pm 0.02^{\mathrm{d}}$ & $8.29 \pm 0.83^{b}$ \\
\hline & 10 & $3.98 \pm 0.01^{\mathrm{e}}$ & $10.98 \pm 0.73^{\mathrm{c}}$ \\
\hline & 12 & $4.87 \pm 0.02^{\mathrm{f}}$ & $14.00 \pm 0.82^{\mathrm{d}}$ \\
\hline \multirow{7}{*}{ 'Namdo' } & 0 & $3.65 \pm 0.05^{\mathrm{a}}$ & $3.05 \pm 0.48^{\mathrm{a}}$ \\
\hline & 2 & $3.76 \pm 0.04^{b}$ & $7.17 \pm 0.73^{\left.\mathrm{b}^{*} 3\right)}$ \\
\hline & 4 & $3.83 \pm 0.04^{\mathrm{c}}$ & $9.87 \pm 0.27^{b^{* *}}$ \\
\hline & 6 & $4.24 \pm 0.01^{\mathrm{d}^{* *}}$ & $13.68 \pm 1.45^{\mathrm{c}^{*}}$ \\
\hline & 8 & $5.17 \pm 0.01^{\mathrm{e}^{* *}}$ & $16.54 \pm 2.44^{\mathrm{c}^{*}}$ \\
\hline & 10 & $5.18 \pm 0.01^{\mathrm{e}^{* *}}$ & $22.73 \pm 2.42^{\mathrm{d}^{* *}}$ \\
\hline & 12 & $6.53 \pm 0.02^{\mathrm{f} * *}$ & $34.16 \pm 1.98^{\mathrm{e}^{* *}}$ \\
\hline
\end{tabular}

${ }^{1)}$ All data are showed as mean \pm SD $(n=3)$.

${ }^{2}$ Different lower case letters indicate the significant differences between aging dates by Duncan's multiple range test $\mathrm{p}<0.05$.

3)* Marks indicate the significant differences between same aging days by Student's t-test ${ }^{*} \mathrm{p}<0.05$ and ${ }^{* *} \mathrm{p}<0.01$.

증가하였는데, 홍산은 숙성 4 일에 생마늘에 비해 약 4.5 배가 증가한 $7.17 \mathrm{QE} \mathrm{mg} / 100 \mathrm{~g}$ 이었고, 숙성 8일까지는 유의적인 차이가 없다가 숙성 10 일에 $10.98 \mathrm{QE} \mathrm{mg} / 100 \mathrm{~g}$ 으로 증가하 였으며, 숙성 12 일에는 $14.00 \mathrm{QE} \mathrm{mg} / 100 \mathrm{~g}$ 이었다. 남도마늘 의 총플라보노이드 함량은 홍산에 비해 유의적으로 더 높았 으며, 생마늘에 비해 숙성 4일에 약 3.3배 증가하여 $9.87 \mathrm{QE}$ $\mathrm{mg} / 100 \mathrm{~g}$ 이었고, 숙성 10 일에는 $22.73 \mathrm{QE} \mathrm{mg} / 100 \mathrm{~g}$, 숙성 12 일에는 $34.16 \mathrm{QE} \mathrm{mg} / 100 \mathrm{~g}$ 으로 최종 숙성 완료된 후에는 홍산에 비해 약 2.44배 더 높았다.

코끼리 마늘과 일반 마늘로 각각 흑마늘을 숙성한 후 총페 놀화합물과 총플라보노이드 함량을 측정한 결과에서도 본 연 구와 유사하게 원료 생마늘에서는 총페놀화합물의 함량에 유 의적인 차이가 없었으나, 숙성 후에는 코끼리 흑마늘에서 그 함량이 유의적으로 더 높았고, 플라보노이드는 생마늘의 경 우 코끼리 마늘에서 유의적으로 함량이 더 높았으며, 숙성 후 에도 이러한 경향이 유지되었다고 보고되어 있다(Kim 등, 2019).

흑마늘 숙성 중 총페놀화합물의 함량은 일반적으로 증가 
하지만, 그 증가 폭은 흑마늘의 숙성 조건에 따라서 서로 상 이하여 $78^{\circ} \mathrm{C}$ 에서 14 일간 숙성할 때보다 $75^{\circ} \mathrm{C}$ 에서 21 일간 숙 성할 때 증가량이 더 높으며, 생마늘 대비 통마늘로 숙성하였 을 때는 약 3 배, 깐마늘로 숙성한 경우는 약 6 배 정도 증가한 다고 보고되어 있다(Angeles 등, 2016).

마늘의 함황화합물이나 페놀화합물 및 플라보노이드와 같 은 구성 성분들은 품종과 여러 재배 조건 등에 영향을 받지만, 재배 조건보다는 품종이 더 유의적인 영향을 미친다는 Martins 등(2016)의 보고로 미루어 볼 때 본 연구 결과에서 플라보노 이드의 함량 차이는 품종의 특성이 영향을 미쳤을 것으로 생 각된다. 총페놀화합물의 경우는 품종에 따른 함량 차이보다 는 세포벽의 파괴에 따른 페놀화합물의 유리 정도와 열처리 에 따른 성분의 분해 속도 차이 등이 더 큰 영향을 미치기 때문에 숙성 정도가 경과함에 따라 함량 차이가 유도된 것으 로 추정된다.

\section{흑마늘 숙성에 따른 pyruvate 및 thiosulfinate 변화}

홍산과 남도마늘 품종으로 각각 흑마늘을 제조하는 동안 pyruvate와 thiosulfinate 함량의 변화는 Fig. 4와 같이 유사한 경향으로 감소하였다. Pyruvate 함량은 마늘의 품종에 따른 유의적인 차이 없이 생마늘에서 홍산은 $10.07 \mathrm{mg} / \mathrm{g}$, 남도마 늘은 $9.83 \mathrm{mg} / \mathrm{g}$ 이던 것이 숙성 기간과 더불어 유의적으로 감 소하여 숙성 12 일에는 각각 $3.66 \mathrm{mg} / \mathrm{g}$ 과 $3.69 \mathrm{mg} / \mathrm{g}$ 으로 차 이가 없었다.

Thiosulfinate는 숙성 전 홍산과 남도마늘에서 각각 5.53 $\mathrm{mg} / \mathrm{g}$ 과 $5.14 \mathrm{mg} / \mathrm{g}$ 으로 홍산에서 유의적으로 높은 함량이었

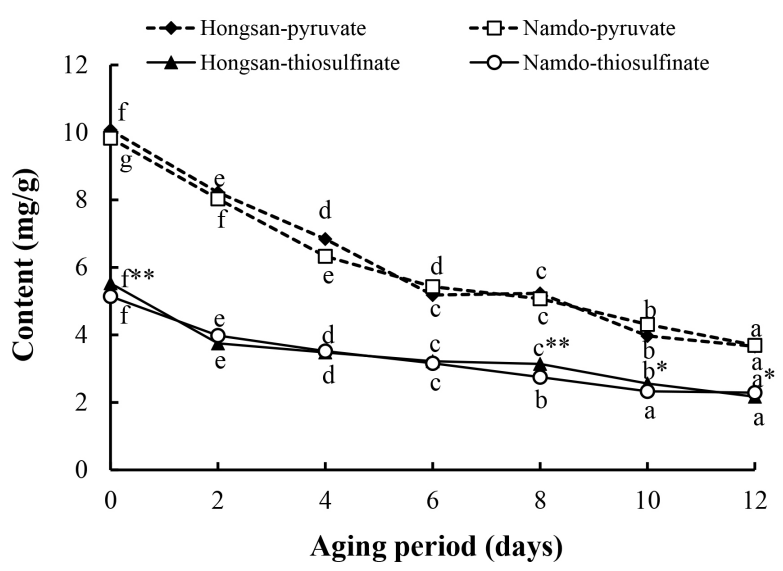

Fig. 4. Changes in pyruvate and thiosulfinate contents according to the aging period of black garlic from 'Hongsan' and 'Namdo' varieies.

All data are showed as mean \pm SD ( $n=3$ ). Different lower case letters indicate the significant differences between aging dates by Duncan's multiple range test $p<0.05$. *Marks indicate the significant differences between same aging days by Student's t-test ${ }^{*} \mathrm{p}<0.05$ and ${ }^{* *} \mathrm{p}<0.01$.
으며, 숙성 2 일에 각각 $32.3 \%$ 와 $22.6 \%$ 씩 감소하여 그 감소 폭이 가장 컸다. 이후에도 $1.7-18.5 \%$ 범위에서 점진적으로 감소하는 경향이었으며 숙성 완료 후에 홍산은 $2.17 \mathrm{mg} / \mathrm{g}$, 남도마늘은 $2.29 \mathrm{mg} / \mathrm{g}$ 이었다.

$\operatorname{Kang}(2016)$ 은 흑마늘 숙성을 5단계로 나누어 총 thiosulfinates와 pyruvate 함량을 분석한 결과, thiosulfinates는 숙성 초기 급감한 후 서서히 감소하였는데 이는 Maillard 반응과 SAC 및 $S$-allylmercapto-cystein(SAMC)이나 다른 물질로 변 화하기 때문으로 추정하였으며, pyruvate는 숙성 초기 크게 증가한 이후 감소하는 경향을 보여 흑마늘에서 마늘 냄새 감 소에 기여한다고 보고한 바 있는데, 이는 본 연구의 결과와 유사한 경향이었다.

이와는 상반되게 자이언트 마늘과 일반 마늘 각각으로 흑 마늘을 만들었을 때 생마늘에 비해 pyruvate 함량은 증가하 였으며, 자이언트 마늘로 제조한 흑마늘에서 유의적으로 함 량이 더 높았다는 보고(Kim 등, 2015)도 있다. 시판 흑마늘 중의 pyruvate와 thiosulfinate 함량은 서로 비례적으로 존재 하며, 마늘의 총 thiosulfinate 함량은 숙성 온도에 따른 큰 차 이는 보이는 것으로 보고되어 있다(Cha 등, 2012). 흑마늘 중 의 pyruvate와 thiosulfinate 함량에 대한 본 연구결과 및 기존 연구결과들 간의 차이와 관련하여 Lee 등(2010)은 숙성 온도 와 기간, 그리고 숙성에 따른 수분 함량 변화로 인해 상대적 인 고형분 함량의 차이, 고온에 의한 당의 분해산물 등이 영 향을 미칠 것으로 추정하였다.

\section{흑마늘 숙성에 따른 SAC 및 $r-G S A C$ 변화}

홍산과 남도마늘의 흑마늘 숙성 중 SAC 및 $\gamma$-GSAC 함량 을 분석한 결과는 Table 3 과 같다. 홍산의 SAC 함량은 생시 료일 때 $49.57 \mathrm{mg} / 100 \mathrm{~g}$ 이던 것이 숙성 2일에 약 3.8 배가 증 가하여 $188.54 \mathrm{mg} / 100 \mathrm{~g}$ 이었다. 숙성 4일에는 236.62 $\mathrm{mg} / 100 \mathrm{~g}$ 으로 증가한 후 숙성 6 일까지는 유의적인 변화 없 이 유지되었다가 그 이후부터는 다시 점차 감소하여 숙성 12 일에는 $142.18 \mathrm{mg} / 100 \mathrm{~g}$ 이었다. 남도마늘의 SAC 함량은 생 마늘에서 $51.17 \mathrm{mg} / 100 \mathrm{~g}$ 으로 홍산과 유의적인 차이가 없었 는데, 숙성 2일에는 $157.94 \mathrm{mg} / 100 \mathrm{~g}$ 으로 약 3배가 증가하여 최고치였고, 그 이후부터는 숙성기간과 더불어 감소하여 숙 성 10 일에 $77.75 \mathrm{mg} / 100 \mathrm{~g}$ 으로 최고치 대비 잔존율은 약 $49 \%$ 에 불과하였다. 숙성 4 일부터는 홍산의 SAC 함량이 남 도마늘에 비해 유의적으로 높았는데, 숙성 12 일에 남도마늘 의 $\mathrm{SAC}$ 함량은 $60.79 \mathrm{mg} / 100 \mathrm{~g}$ 으로 홍산의 $42.8 \%$ 에 불과하 였다.

본 연구의 결과, 생마늘 대비 최종 숙성 완료된 흑마늘에 서 $\mathrm{SAC}$ 함량은 홍산은 약 2.9 배, 남도마늘은 약 1.2 배 더 높 았다. 이는 마늘 숙성 전후의 SAC 함량과 관련하여 생마늘 
Table 3. Changes in SAC and $\gamma$-GSAC contents according to the aging period of black garlic from 'Hongsan' and 'Namdo' varieties $(\mathrm{mg} / 100 \mathrm{~g})$

\begin{tabular}{|c|c|c|c|}
\hline $\begin{array}{l}\text { Species of } \\
\text { garlic }\end{array}$ & $\begin{array}{l}\text { Aging } \\
\text { days }\end{array}$ & SAC & $\gamma$-GSAC \\
\hline \multirow{7}{*}{ 'Hongsan' } & 0 & $49.57 \pm 7.61^{1 \mathrm{a} 2)}$ & $230.86 \pm 71.19^{\mathrm{cd}}$ \\
\hline & 2 & $188.54 \pm 27.25^{\mathrm{c}}$ & $274.64 \pm 28.67^{\left.\mathrm{d}^{*} 3\right)}$ \\
\hline & 4 & $236.62 \pm 35.32^{\mathrm{d}^{*}}$ & $184.84 \pm 14.79^{\mathrm{bc} * *}$ \\
\hline & 6 & $236.76 \pm 24.25^{\mathrm{d}^{* *}}$ & $151.98 \pm 11.20^{\mathrm{ab} * *}$ \\
\hline & 8 & $204.93 \pm 29.10^{\mathrm{cd}^{* *}}$ & $130.29 \pm 8.09^{\mathrm{ab} * *}$ \\
\hline & 10 & $190.94 \pm 15.49^{\mathrm{c}^{* *}}$ & $129.71 \pm 8.53^{\mathrm{ab}^{* *}}$ \\
\hline & 12 & $142.18 \pm 13.94^{\mathrm{b}^{* *}}$ & $94.72 \pm 12.42^{\mathrm{a}^{* *}}$ \\
\hline \multirow{7}{*}{ 'Namdo' } & 0 & $51.17 \pm 6.23^{\mathrm{a}}$ & $106.92 \pm 5.60^{8 d}$ \\
\hline & 2 & $157.94 \pm 13.89^{\mathrm{d}}$ & $145.78 \pm 7.34^{\mathrm{e}}$ \\
\hline & 4 & $116.00 \pm 19.01^{\mathrm{c}}$ & $60.21 \pm 15.84^{\mathrm{c}}$ \\
\hline & 6 & $103.94 \pm 18.22^{\mathrm{bc}}$ & $55.21 \pm 10.23^{\mathrm{c}}$ \\
\hline & 8 & $80.35 \pm 14.76^{\mathrm{ab}}$ & $40.76 \pm 1.87^{\mathrm{b}}$ \\
\hline & 10 & $77.75 \pm 9.75^{\mathrm{a}}$ & $35.29 \pm 1.38^{\mathrm{b}}$ \\
\hline & 12 & $60.79 \pm 6.06^{\mathrm{a}}$ & $15.81 \pm 1.61^{\mathrm{a}}$ \\
\hline
\end{tabular}

${ }^{1)}$ All data are showed as mean \pm SD $(n=3)$.

${ }^{2}$ Different lower case letters indicate the significant differences between aging dates by Duncan's multiple range test $\mathrm{p}<0.05$.

3)* Marks indicate the significant differences between same aging days by Student's t-test ${ }^{*} \mathrm{p}<0.05$ and ${ }^{*} \mathrm{p}<0.01$.

대비 건물량으로 약 5.6배가 증가하였다는 보고(Bae 등, 2014)와 숙성 완료 후 약 6배가 증가하였다는 보고(Hanum 등, 1995), 생마늘 착즙액 대비 흑마늘 착즙액에서는 약 3.3 배가 증가하였다는 보고(Kim 등, 2017) 및 생마늘 대비 흑마 늘에서 약 2.2배가 증가하였다는 보고(Kim 등, 2012) 등과 비교해 볼 때 증가하는 경향은 일치하였으나 그 절대값은 차 이가 있었다. 이러한 차이는 각 연구마다 흑마늘의 숙성 조건 이 서로 상이하고, 원료 마늘 중의 SAC 함량 및 보관상태 등이 상이하기 때문으로 추정되는데, Kim 등(2012)은 생마 늘을 $4^{\circ} \mathrm{C}$ 의 저온에서 1 개월 저장하였을 때 $\mathrm{SAC}$ 함량은 약 8 배 정도 증가하였음을 보고한 바 있다.

$\gamma-\mathrm{GSAC}$ 함량은 홍산과 남도마늘이 유사한 변화의 경향을 보여 생마늘에 비해 유의적으로 증가하여 숙성 2일 차에 최고 치였으며, 그 이후부터는 다시 감소하였다. 숙성 전 생마늘에 서 $\gamma$-GSAC 함량은 홍산과 남도마늘에서 각각 $230.86 \mathrm{mg} / 100$ $\mathrm{g}$ 과 $106.92 \mathrm{mg} / 100 \mathrm{~g}$ 으로 홍산에서 약 2.2배 더 높은 함량이 었고, 숙성이 완료된 12 일 차에는 각각 $94.72 \mathrm{mg} / 100 \mathrm{~g}$ 과 $15.81 \mathrm{mg} / 100 \mathrm{~g}$ 으로 잔존율은 각각 $41 \%$ 와 $14.8 \%$ 였다.
흑마늘의 숙성 동안 $\gamma$-GSAC는 $\gamma$-GTP에 의해 분해되어 $\mathrm{SAC}$ 로 전환되는데, 마늘 중의 수분은 $\gamma$-GTP에 의한 가수분 해를 도와주어 $\gamma$-GSAC로부터 SAC의 생성을 증가시키지만, 고온에서 마늘을 가열하게 되면 수분의 손실이 일어나면서 $\gamma$-GTP의 활성도 낮아지게 되므로 $\gamma$-GSAC로부터 $\mathrm{SAC}$ 의 생 성 반응은 아직은 알려지지 않은 여러 요인들이 관여한다는 Bae 등(2014)의 보고가 있다.

\section{요 약}

국립원예특작과학원에서 우수 마늘품종으로 개발된 '홍 산'과 남해군에서 주로 재배되고 있는 '남도'마늘로 동일한 조건에서 흑마늘을 숙성하면서 품질특성을 비교 분석하였다. 홍산과 남도마늘의 총페놀화합물은 숙성 완료 후 생마늘에 비해 각각 1.3 배와 1.7 배 증가하였고, 총플라보노이드 함량은 각각 8.6배와 11.2배가 증가하였다. Pyruvate와 thiosulfinate 함량은 홍산과 남도마늘 모두 숙성 기간에 따라 감소하는 경 향이었다. SAC 함량은 홍산은 숙성 6일에 $236.76 \mathrm{mg} / 100 \mathrm{~g}$ 으로 가장 높다가 이후 감소하였고 남도마늘은 숙성 2 일에 $157.94 \mathrm{mg} / 100 \mathrm{~g}$ 으로 가장 높다가 이후 감소하여 숙성 12 일 에는 $60.79 \mathrm{mg} / 100 \mathrm{~g}$ 였다. 생마늘의 SAC 함량은 남도마늘 이 약 3\% 더 높았으나 숙성완료 후에는 홍산에서 남도마늘 보다 약 2.3 배 더 높았다. 생마늘의 $\gamma$-GSAC 함량은 홍산에 서 남도마늘보다 약 2.2배 더 높았으며, 품종에 관계없이 숙 성 2 일 차에 최고치를 보인 이후부터는 숙성기간과 더불어 감소하였다. 마늘의 품종은 숙성된 흑마늘의 수분, $\mathrm{pH}$, 산도, 환원당과 총당, pyruvate, thiosulfinate 함량에는 큰 영향을 미치지 않았으나, 총페놀화합물과 총플라보노이드 함량은 남 도마늘에서 더 높았고, 경도, SAC와 $\gamma$-GSAC의 함량은 홍산 으로 제조한 흑마늘에서 더 높았다. 이러한 차이는 원료인 생 마늘 중 이들 성분의 함량에 영향을 받는 것으로 생각된다.

\section{Conflict of interests}

The authors declare no potential conflict of interest.

\section{ORCID}

Min Jung Kang https://orcid.org/0000-0003-4500-9538

Jung Hye Shin https://orcid.org/0000-0002-1505-1965

\section{References}

Angeles TMM, Jesús PA, Rafael MR, Tania MA. Evolution of some physicochemical and antioxidant properties of 
black garlic whole bulbs and peeled cloves. Food Chem, 199, 135-139 (2016)

Ashafaq M, Khan MM, Raza SS, Ahmad A, Khuwaja G, Javed H, Khan A, Islam F, Siddiqui MS, Safhi MM, Islam F. S-allyl cysteine mitigates oxidative damage and improves neurologic deficit in a rat model of focal cerebral ischemia. Nutr Res, 32, 133-143 (2012)

Bae SE, Cho SY, Won YD, Lee SH, Park HJ. Changes in S-allyl cysteine contents and physicochemical properties of black garlic during heat treatment. LWT-Food Sci Technol, 55, 397-402 (2014)

Baumgartner S, Dax TG, Praznik W, Falk H. Characterisation of the high-molecular weight fructan isolated from garlic (Allium sativum L). Carbohydr Res, 328, 177-183 (2000)

Cha HS. Physicochemical properties and antioxidant activity of black garlic (Allium sativum L.) depend on aging periods. MS Thesis, Kyung Hee University, Korea, p 41-42 (2012)

Cha JY, Lee SJ, Shin JH, Sung NJ. Antioxidant and inhibition of nitrosodimetnylamine formation in marketing black garlics. J Agric Life Sci, 46, 151-162 (2012)

Chao HM, Chen IL, Liu JH. S-allyl L-cysteine protects the retina against kainate excitotoxicity in the rat. Am J Chin Med, 42, 693-708 (2014)

Chen J, Cheong KL, Song Z, Shi Y, Huang X. Structure and protective effect on UVB-induced keratinocyte damage of fructan from white garlic. Carbohydr Polym, 92, 200-205 (2013)

Chen Z, Xu M, Wang C, Zhou H, Fan L, Huang X. Thermolysis kinetics and thermal degradation compounds of alliin. Food Chem, 223, 25-30 (2017)

Choi HJ, Lim BR, Ha SC, Kwon GS, Kim DW, Joo WH. Physicochemical characteristics and antioxidant activities of freezing pretreated black garlic. J Life Sci, 27, 471-475 (2017)

Choi JH, Kim WJ, Yang JW, Sung HS, Hong SK. Quality changes in red ginseng extract during high temperature storage. J Korean Soc Appl Biol Chem, 24, 50-58 (1981)

Colin-Gonzalez AL, Ali SF, Tunez I, Santamaria A. On the antioxidant, neuroprotective and anti-inflammatory properties of S-allyl cysteine: An update. Neurochem Int, 89, 83-91 (2015)

Folin O, Denis W. A colorimetric method for the determination of phenols (and phenol derivatives) in urine. J Biol Chem, 22, 305-308 (1915)

Freeman GG, Mcbreen F. A rapid spectrophotometric method of determination of thiolsulphinate in onion (Allium cepa) and its significance in flavour studies. Biochem Soc Trans, 1, 1150-1152 (1973)

Garcia E, Santana-Martinez R, Silva-Islas CA, ColinGonzalez AL, Galvan-Arzate S, Heras Y, Maldonado PD, Sotelo J, Santamaria A. S-allyl cysteine protects against MPTP-induced striatal and nigral oxidative neurotoxicity in mice: participation of Nrf2. Free Radic Res, 48, 159-167 (2014)

Han JW. Effect of genotype and environment on agricultural characteristics and alliin in garlic. MS Thesis, Konkuk University, Korea, p 28-30 (2019)

Hanum T, Sinha NK, Guyer DE, Cash JN. Pyruvate and flavor development in macerated onions (Allium cepa L.) by $\gamma$-glutamyl transpeptidase and exogenous C-S lyase. Food Chem, 54, 183-188 (1995)

Ha SM, Choi HJ, Shin GY, Ryu BH, Joo WH. Fermentation of black garlic wine and its characteristics. J Life Sci, 26, 796-804 (2016)

Jung DY, Choi JH, Kim JS, Choi HS, Bae MJ, Park WS, Min BI. The protective effects of black garlic extract for blood and Intestinal mucosa to irradiation. $\mathrm{J}$ Radiological Sci Technol, 39, 19-26 (2016)

Kang MJ, Yoon HS, Jeong SH, Sung NJ, Shin JH. Physicochemical characteristics of red garlic during processing. Korean J Food Preserv, 18, 898-906 (2011)

Kang OJ. Physicochemical characteristics of black garlic after different thermal processing steps. Prev Nutr Food Sci, 21, 348-354 (2016)

Kim D, Kim KH, Yook HS. Analysis of active components of giant black garlic. J Korean Soc Food Sci Nutr, 44, 1672-1681 (2015)

Kim D, Kim KH, Yook HS. Comparison of antioxidant activity between black elephant garlic (Allium ampeloprasum) and black normal garlic (Allium sativum L.). J Korean Soc Food Sci Nutr, 48, 1352-1358 (2019)

Kim JH, Nam SH, Rico CW, Kang MY. A comparative study on the antioxidative and anti-allergic activities of fresh and aged black garlic extracts. Int J Food Sci Technol, 47, 1176-1182 (2012)

Kim JH, Yu SH, Cho YJ, Pan JH, Cho HT, Kim JH, Bong HJ, Lee YJ, Chang MH, Jeong YJ, Choi GR, Kim YJ. 
Preparation of S-allylcysteine-enriched black garlic juice and its antidiabetic effects in streptozotocin-induced insulin-deficient mice. J Agric Food Chem, 65, 358-363 (2017)

Kim JS, Ra JH. Comparison of phytochemical composition and physiological activity of 'Hongsan' and 'Hansan', a new variety of garlic. Korean J Food Sci Technol, 51, 147-151 (2019a)

Kim JS, Ra JH. Comparison of the major compounds and antimicrobial activities of Korea garlic cultivated in different regions. Korean J Food Sci Technol, 51, 258262 (2019b)

Kim MS, Kim MJ, Bang WS, Kim KS, Park SS. Determination of S-allyl-L-cystein, diallyl disulfide, and total amino acids of black garlic after spontaneous short-term fermentation. J Korean Soc Food Sci Nutr, 41, 661-665 (2012)

Kim SD, Do JH, Oh HI. Antioxidant activity of Panax ginseng browning products. J Korean Agric Chem Soc, 24, 161-166 (1981)

Kimura S, Tung YC, Pan MH, Su NW, Lai YJ, Cheng KC. Black garlic: A critical review of its production, bioactivity, and application. J Food Drug Anal, 25, 62-70 (2017)

Krause RJ, Glocke SC, Elfarra AA. Sulfoxides as urinary metabolites of S-allyl-L-cysteine in rats: Evidence for the involvement of flavin-containing monooxygenases. Drug Metab Dispos, 30, 1137-1142 (2002)

Lee KH, Yoon YT. Antioxidant activity of kimchi seasoning with black garlic. Korean J Food Nutr, 30, 175-180 (2017)

Lee SJ, Shin JH, Kang MJ, Jung WJ, Ryu JH, Kim RJ, Sung NJ. Antioxidant activity of aged red garlic. J Life Sci, 20, 775-781 (2010)

Liang T, Wei F, Lu Y, Kodani Y, Nakada M, Miyakawa T, Tanokura M. Comprehensive NMR analysis of compositional changes of black garlic during thermal processing. J Agric Food Chem, 63, 683-691 (2015)

Martins N, Petropoulos S, Ferreira I CFR. Chemical composition and bioactive compounds of garlic (Allium sativum L.) as affected by pre- and post-harvest conditions: A review. Food Chem, 211, 41-50 (2016)

Moreno MIN, Isla MI, Sampietro AR, Vattuone MA. Comparison of the free radical-scavenging activity of propolis from several region of Argentina. J Ethnopharmacol, 71,
109-114 (2000)

Rural Development Administration (RDA). http://www.nong saro.go.kr/portal/ps/psb/psbk/kidofcomdtyDtl.ps?menuId $=$ PS00067\&kidofcomdtyNo=27207 (2017) (accessed Apr il 2020)

Rural Development Administration (RDA). http://www.rda. go.kr/viewer/doc.html?fn=farmprmninfo 1000007466490 \&rs=/upload/board/farmprmninfo/result/202004/ (2018) (accessed April 2020)

Rural Development Administration (RDA). http://www.rda. go.kr/viewer/doc.html?fn=farmprmninfo 1000007556090 \&rs=/upload/board/farmprmninfo/result/202004/ (2019) (accessed April 2020)

National Institute of Horticultural and Herbal Science (NIHHS). http://www.nihhs.go.kr/search/search_index.do (2015)

Rural Development Administration (RDA). http://www.nong saro.go.kr/portal/contentsFileView.do? cntntsNo $=211674$ $\&$ fileSeCode $=185001 \&$ fileSn $=1$ (accessed April 2020)

Schwimmer S, Weston WJ. Onion flavor and odor, enzymatic development of pyruvic acid in onion as a measure of pungency. J Agric Food Chem, 9, 301-304 (1961)

Seo WT, Choi MH, Sim HJ, Kim GW, Shin YM, Kang MJ. Quality characteristics of vinegar fermented with different amounts of black garlic and alcohol. Korean J Food Preserv, 23, 34-41 (2016)

Shin JH, Choi DJ, Chung MJ, Kang MJ, Sung NJ. Changes of physicochemical components and antioxidant activity of aged garlic at different temperatures. J Korean Soc Food Sci Nutr, 37, 1174-1181 (2008)

Shin JH, Kang MJ, Kim KH, Yang JS. Aged garlic and manufacturing method thereof. Korea Patent No. 10-1989494 (2019)

Sim HJ, Kang MJ, Kim GM, Lee CK, Kim JH, Shin JH. Optimization of soy sauce production conditions with black garlic extract by response surface methodology. Korean J Food Cook Sci, 32, 307-315 (2016)

Yuan H, Sun L, Chen M, Wang J. An analysis of the changes on intermediate products during the thermal processing of black garlic. Food Chem, 239, 56-61 (2018)

Zhang X, Li N, Lu X, Liu P, Qiao X. Effects of temperature on the quality of black garlic. J Sci Food Agric, 96, 2366-2372 (2016) 